\title{
Legal Protection for Investors in Purchasing Land for Business Interests
}

\author{
I Wayan Gde Wiryawan \\ \{gdewiryawan1976@gmail.com\} \\ Faculty of Law, Universitas Mahasaraswati, Denpasar, Bali-Indonesia
}

\begin{abstract}
In attracting investors to invest their capital in Indonesia, the government undertakes a series of policies to facilitate the movement of investors. However, investors are often confronted with various issues in relation to the business world; legal protection for investors in the purchase of land needs to be done to ensure legal certainty and improved the conduciveness of business climate. In this study, there are two issues that will be discussed: how is the Indonesian government's policy in the field of investment and how are the efforts to prevent problems in the purchase of land by investors? This research is a normative legal research. To prevent problems in purchasing land in the future, investors need to know the rule of law in Indonesia. Each stage to purchase land need to be done by law and set forth in the form of agreement and notarial deed.
\end{abstract}

Keywords: Investor; land; legal protection

\section{Introduction}

The term investment is a well-known term, both in business activity and within a statutory rule. It is a popular term in the business world [1]. Investment activities are not only conducted within a single country, but are conducted across borders [2]. In dealing with investment between countries, countries in the world have formed The International Center for the Settlement of Investment Disputes ("ICSID"). ICSID is an organization created by the Washington Convention ("the Convention" or "the ICSID Convention") to facilitate international investment by creating a body to settle disputes between investors and states that may arise from such investments [3]. Investment activity is a sector that is quite vulnerable to legal issues $[4,5,6]$, therefore; investment policy becomes a vital policy in government.

Investment policy is an important discourse in a country's economic development [7]. Policy is a strategic utilization of existing resources to solve public or government problems. Policy is a form of state intervention to protect the interests of disadvantaged (group) people [8]. Government in determining the policy need to pay attention to factors influencing investment. There are many factors that influence investors in investing their capital. Capital investment that has a primary goal to gain maximum profit (profile oriented) and the secondary objective is to produce goods. However before deciding to put investment, there are many things that need to be taken into account. 
Therefore, the government should try to facilitate to create a good and conducive atmosphere so that investors are interested to invest their capital. In investment, the government should pay attention to internal and external factors of capital investment. The factors include [9].

a. Internal factors

- Investors generally complain about investment procedures that are considered convoluted and too bureaucratic. Therefore, it is needed to create the easier procedure handling through one gate service or one top service.

- Uncertain political and security conditions. Investors need security guarantees of their capital and their lives. Tribal dispute in several regions in Indonesia such as Ambon, Sampit, Aceh and Papua make threats to foreign investors.

- Investment business field. Investment business sector should be adjusted by government policy. Open and closed business fields for foreign investors should be clearly defined.

- The quality and ability of the workforce is not good. Labor factors become one of important consideration factor because it is related to production quality. So also with the wages of workers and work ethic, behavior and culture of the workers.

- Land ownership rights. This land ownership rights are generally very difficult to be obtained by foreign investors who will invest their capital in Indonesia. The worry if foreign investors are given the right to own land then they have the opportunity to control the land on a large scale that is feared could harm the national interest. While other countries such as China, Thailand and the Philippines have started to offer various land rights that appeal to foreign investors.

- Aspects of protection and legal certainty. The Investment Law does not guarantee legal protection and certainty for investors. Moreover, the changing and less synchronization of the rules with each other makes foreign investors confused in interpreting them.

- Lack of incentive facilities. Various incentive facilities are essential to attract foreign investors. There are increasing competitions among developing countries to attract foreign investors to make foreign capital inflows into their countries. It makes countries offer a lure of incentives, like sweet sugar for investors. Therefore, investors are like ants flocking to the lucrative region to make a profit.

b. External factors

- Interdependence between countries. There is no country in the world that can fulfill all the needs of its own people. The differences in geographical location, capital, natural potential, population, scientific ability and others make the countries mutually need each other, including to meet the economic needs through investment

- Globalization and international economic liberalization. With the agreement of the international community to globalize and liberalize the economy world, the investment sector becomes widespread and almost without obstacles. Through various international economic agreement commitments such as the World Trade Organization (WTO) and various regional economic partnerships such as the European Union (EU), the Eruropean Free Trade Area (EFTA), the North American Free Trade Area (EFTA) NAFTA), the Asia Pasific Economic Coorporation (APEC), the Asean Free Trade Area (AFTA) and the rest are agreed to not only establish free trade area but also free investment area. 
- Fierce competition between developing countries. Commitment to establish the area of free trade and investment is increasingly causing competition in the field of investment higher. Particularly among the developing countries, they compete each other to "beautify themselves" to attract foreign investor from the developed countries to enter their country.

Land ownership factor is an important concern for investors in Indonesia. Land in Indonesia cannot be bought by investors. Land in Indonesia can only be purchased by Indonesian citizens. As a result, only domestic investors can buy land for business purposes, while foreign investors need to work with Indonesians in order to get the land used to build their business. Problems of buying and selling land for business interests are often faced with the origin of the land that is still in dispute. Moreover, in some cases, the land comes from inheritance. Investors are also faced with multiple certificate ownership issues. These conditions certainly do not provide assurance of legal certainty from investors. This will reduce investor confidence to invest in Indonesia.

The study is designed in a normative study approach, where actions were done to investigate legal provisions of Indonesia country on investment on land for business purposes. We collected the related regulations of law and related theories of investing, land purchasing, and business. We interpreted the verse in each utilized sources of law as object-related material for the study.

\section{Discussion}

\subsection{The Indonesian Government's Policy in the Field of Investment}

Indonesia is one of potential places to invest for investors in the field of goods and services, mining, and tourism. The US News survey was obtained taking into account data released by the United Nations Office for Trade and Development (UNTCD) and the World Bank. Afterwards, US News surveyed 21000 respondents from 80 countries. Reported by Business Insider, Indonesia is considered to have steady economic growth in the next few years. United Nations Conference on Trade and Development (UNCTD) data shows Indonesia as one of the promising countries in receiving foreign investment. The rating of Indonesia as an investment-worthy country beats other Southeast Asian countries such as Malaysia and Singapore. Malaysia sits fourth while Singapore sits in fifth place [10]. To support the investment passion, the government issued a number of policies in the field of investment.

Investment activities in Indonesia are regulated in The Act of Republic of Indonesia Number 25 of 2007 regarding Capital Investment. In the provision of Article 1 Sub-Article 1 of Capital Investment Act stipulated that what is meant by investment is any form of investment activity, either by domestic or foreign investor to do business in the territory of the Republic of Indonesia. Investment policy is regulated in Article 4 Capital Investment Act. In the provision is stipulated on:

a. The Government shall determine the basic policy of investment for:

- encouraging the creation of a conducive national business climate for investment to strengthen the competitiveness of the national economy; and

- accelerating the increase of investment.

b. In determining the basic policy referred to in paragraph (1), the Government: 
- giving equal treatment to domestic and foreign investors with due regard to national interests;

- ensuring legal certainty, business certainty, and security of business for investors since the process of licensing until the end of investment activities in accordance with the provisions of legislation; and

- opening opportunities for development and providing protection to micro, small, medium and cooperative enterprises.

c. The basic policy referred to in paragraph (1) and paragraph (2) shall be realized in the form of the General Plan of Investment.

Investment policy is a very important policy in national development. Capital investment develops in line with a country in implementing national development to improve the welfare and prosperity of its people. These needs arise due to the inability of a country to meet the needs of capital so that capital becomes one of the best alternatives other than through foreign debt [9]. In practice, the term investment itself is often used in different meanings. Komaruddin gives understanding of the investment in three meanings:

a. An act to buy shares, bonds or other letters of participation.

b. An action to buy capital goods.

c. Utilization of funds available for production with future earnings results.

In terms of shape, investment can be distinguished between direct investments and portfolio investments, or equity participation (without a majority). The difference is at the level of power. In direct investments, the foreign party controls the management of the company, so that investors begin to be involved since giving their capital to a business, managing to oversee the field of business. In indirect investments portfolio, investors are actively involved in management. Investments are made through bond ownership and shares. There is also an export credits called short-term loan that provides an opportunity for employers or government agencies in developing countries to purchase capital equipment and equipment in the form of credit.

Investment activities consist of domestic and foreign investment. In Article 1 point 2 of the Capital Investment Act, domestic investment is an activity of investing to conduct business in the territory of the Republic of Indonesia carried out by domestic investors using domestic capital "whereas in Article 1 point 3 of the Capital Investment Act stated that" Foreign investment is an activity of investing to conduct business in the territory of the Republic of Indonesia conducted by foreign investors, whether using foreign capital completely or in association with domestic investors. "

The Government provides that foreign investment must use Indonesian legal entities. There are 2 (two) reasons why any foreign investment must use Indonesian legal entity i.e. the investor can easily apply the provisions under Indonesian law and facilitate the jurisdiction in case of arise or dispute. By using a legal entity means an investor may act as a proprietor of rights and obligations (rechtperson) which has its own property, whether in the form of capital of company equipment and others that can be used as security against negligence in the fulfillment of obligations.

Government policy on investment cannot be separated from the benefits of investment itself for the government. Two (2) main benefits of investment for the Indonesian government are as follows: 
a. Increased real incomes, reflected in increased levels of income for consumers, or increased government revenues.

b. Indirect benefits such as introduction of new technologies and knowledge.

William A. Fennel and Joseph W. Tyler and Eric M. Burt identified positive impacts for both the recipient country and the beneficiary population. The advantages of the investment are as follows:

a. Giving working capital.

b. Bringing expertise, managerial, science, capital and market connections.

c. Increasing foreign money revenues through export activities by multinational companies.

d. Foreign investment does not give birth to new debt.

e. The recipient country is not concerned or at risk when a PMA entering the country, it does not profit from the capital it receives.

f. Assisting development efforts to the economies of recipient countries.

Muchammad Zaidun in his scientific oration, put forward the theories related to the interests of the state in the field of investment. The review is from the point of view of the interests of economic development, that is, from the point of view of economic interests that form the basis of the consideration of policy formulation, usually use the theories of Development Economics, as the basis of the investment policies that are quite popular like:

a. Neo-Classical Economic Theory,

This theory argues that Foreign Direct Investment (FDI) has a positive contribution to the economic development of the host country. This fact shows that foreign capital brought to host country also encourages domestic capital to use it for various businesses. It is in line with Sornarajah's conclusion that foreign investment as a whole is beneficial to host country to encourage economic growth and national development [11].

b. Dependency Theory,

This theory is diametrically opposed to the classical economy that argues that foreign investment does not give any meaning to economic development in the host country. They argue that foreign investment is suppressing economic growth and raising the income imbalance in the host country as stated by Rothgeb. The theory also argues that FDI appears to be a threat to host country sovereignty and to the freedom of social and cultural development. Due to foreign investment, there is a tendency to extend jurisdiction using the influence of foreign government forces on the host country so that the foreign policy influence of foreign investment on host country is considerable [11].

c. The Middle Path Theory

Many developing countries develop regulation such as regulating the removal in licensing and incentives through investment policy. According to this theory, foreign investment has a positive aspect as well as a negative aspect to host country, therefore; the host countries should be cautious and prudent. Such prudence and wisdom can be undertaken by developing a fair regulatory policy.

d. State/Government Intervention Theory,

Proponents of this theory argue that the protection of invant industries in developing countries from competence with industry in developed countries is essential for national development.

The state has an interest in making investment policy. The investment policy does not only deal with financial gain, but also how the state protects the national interest. In protecting the national interest, the state has a policy of land ownership for business purposes. 


\subsection{The Effort to Prevent Dispute in Buying Land by Investors}

From an economic point of view in which the investment is as one of the factors of production, investment can be interpreted as an action to buy stocks, bonds, or any other participation; an act of buying capital goods; and the utilization of funds available for production with future opinions [12]. Investment policy is subject to Capital Investment Act. Article 25 of the Capital Investment Act states:

a. Investors who invest in Indonesia must comply with the provisions of Article 5 of this Act.

b. Ratification of the incorporation of a domestic investment company in the form of a legal entity or non-legal entity shall be conducted in accordance with the provisions of laws and regulations.

c. Ratification of establishment of foreign investment company in the form of a limited liability company shall be conducted in accordance with the provisions of laws and regulations.

d. Investment companies that will conduct business activities shall obtain permits in accordance with the provisions of the laws and regulations of the authorized agencies, unless otherwise provided in law.

e. Permit as referred to in paragraph (4) shall be obtained through one-door integrated service.

Domestic investment may be made in the form of a business entity in the form of a legal entity, not legal entity or sole proprietorship, in accordance with the provisions of legislation. Foreign investment shall be in the form of a limited liability company under Indonesian law and domiciled within the territory of the Republic of Indonesia, unless otherwise provided by law. Domestic and foreign investors engaged in investments in the form of limited liability companies shall be conducted with:

a. taking part of the shares at the time of the establishment of a limited liability company;

b. buying shares; and

c. to perform other means in accordance with the provisions of legislation.

Efforts to prevent the occurrence of disputes in the purchase of land in Indonesia are done by studying Indonesian Law. Normatively, land can only be owned by Indonesians. This provision is stipulated in Article 21 paragraph (1) of Law No. 5 of 1960 on Basic Agrarian Principles which states "Only Indonesian citizens can have property rights." To overcome these obstacles, foreign investors usually conduct a nominee agreement. Nominee is "one designated to act for another as his representatives in a rather limited sense. It is used sometimes to signify an agent or trustee. It has no connotation, however, other than that of acting for another, in representation of another, or as the grantee of another" [13]. Nominee is a person or individual who is appointed to specially act on behalf of the person who appointed him (beneficiary) to perform a certain act or legal action. Nominee may be appointed to take legal action, among others, as property owner or land, as director, as authorized, as shareholder and others [14].

The provisions of Law Number 25 of 2007 regarding Capital Investment prohibit the making of nominee agreement. Article 33 Paragraph (1) states "domestic investment and foreign capital investments in the form of a limited liability company are prohibited from entering into agreements and/or statements confirming the ownership of shares in limited liability companies for and on behalf of others." The nominee agreement is a legal smuggling that allows foreigners to control land in Indonesia. This condition is certainly very detrimental to the state. The use of Indonesian names in the purchase of land is actually detrimental to foreign investors. Foreign investors may lose their land when the Indonesians violate the agreement. 
The purchase of land by investors undertaken in several stages must be done by contract. The contract is one of two existing legal bases other than the law that may cause the engagement. Engagement is a legal relationship that binds one or more legal subjects to related obligations to each other [15]. The seller and the buyer of the land have a legal relationship affirmed in the sale and purchase agreement [16]. A legal relationship is a relationship that is regulated and recognized by law. The relationship recognized by law is usually called an engagement because of the agreement. It is said that, because the legal relationship has been made by the parties (legal subject) in such a way that it binds both parties and acts as a law. The contract serves to legitimize legal relations between investors who buy land and landowners as sellers.

The sale and purchase agreement specifies the rights and obligations of the seller and the buyer. The agreement is binding on both sides that make it [17]. The provisions concerning the sale and purchase are regulated in Article 1457 of the Civil Code which states "Sell-purchase is an agreement by which one party binds him to deliver a good, and the other to pay the promised price." In the process of purchasing land, the buyer does not immediately pay off the payment. Buyers make payments in several stages. The legal relationship between the seller and the buyer is done by binding of the sale and purchase. In the sale and purchase binding deed, the seller (the first party) provides a guarantee to the buyer (second party) on the land to be traded:

a. is indeed belonging to the first party itself and only the first party itself is entitled to hand over;

b. not subject to any confiscation or burden as a guarantee of a debt;

c. that now and in the future the second party will not be prosecuted by other party claiming to have or participate in the right to such land, and hence the second party is hereby acquitted by the first party of any other party's claims regarding it.

Basically, investors, both domestic and foreign investors who invest in Indonesia are given various facilities. The granting of this facility is intended to make domestic and foreign investors willing to invest in Indonesia. The investment is needed by the Indonesian government to accelerate the development process. The investments invested by investors have very important role for the community because these investments have an effect on the lives of local communities $[8]$.

\section{Conclusion}

The Indonesian government's policy on investment is done by creating a set of legal rules that provide legal certainty to investors. The efforts to protect investors in the purchase of land for business purposes are with an understanding of the rule of law in Indonesia, in which the land can only be owned by Indonesians only. The investment policy in Indonesia also prohibits the nominee agreement. In protecting the parties, both the seller and the buyer, then every stage of the land transaction needs to be done through the notarized contract.

\section{References}

[1] Supancana, I, B, R.: Kerangka Hukum dan Kebijakan Investasi Langsung. Bogor. Ghalia (2006)

[2] Berry, S.: Building for the Future? Investment, Land Reform and the Contingencies of Ownership 
in Contemporary Ghana. World Dev. vol. 37 (8) pp. 1370-1378 (2009)

[3] Grabowski, A.: The Definition of Investment under the ICSID Convention: A Defense of Salini. Chicago J. Int. Law. vol. 15 (1). p. 289 (2014)

[4] Deininger, K and Chamorro, J, S.: Investment and equity effects of land regularisation: The case of Nicaragua. Agric. Econ. vol. 30 (2). pp. 101-116 (2004)

[5] Pannell, D, J, Roberts, A, M, Park, G, Alexander, J, Curatolo, A and Marsh, S, P.: Integrated assessment of public investment in land-use change to protect environmental assets in Australia. Land use policy. vol. 29 (2). pp. 377-387 (2012)

[6] Turnbull, G, K.: The investment incentive effects of land use regulations. J. Real Estate Financ. Econ. vol. 31 (4). pp. 357-395 (2005)

[7] Lee, W and Naito, T.: Compensation rules and investment under land-taking. Rev. Urban Reg. Dev. Stud. vol. 14 (1). pp. 78-94 (2002)

[8] Salim, B, H dan Sutrisno.: Hukum Investasi di Indonesia. Jakarta. Rajawali Press (2014)

[9] Rakhmawati, R.: Hukum Penanaman Modal di Indonesia. Malang. Bayu Media (2004)

[10] Muliana, A, M.: Indonesia Jadi Negara Tujuan Investasi Kedua Terbaik di Dunia - Bisnis Liputan6.com (2018)

[11] Zaidun, M.: Penerapan Prinsip-Prinsip Hukum Internasional Penanaman Modal Asing di Indonesia (Ringkasan Disertasi). Airlangga University Surabaya (2005)

[12] Anoraga, P.: Perusahaan Multinasional dan Penanaman Modal Asing. Jakarta. Pustaka Jaya (1994)

[13] Gamer, B, A.: Black's Law Dictionary with Guide to pronuncition. St. Paul. West Publishing (1992)

[14] Hasibuan, N.: Perjanjian Nominee yang Dibuat untuk Penguasaan Tanah Hak Milik Warga Negara Indonesia oleh Warga Negara Asing. Brawijaya University Malang (2012)

[15] Fuady, M.: Hukum Kontrak (Dari Sudut Pandang Hukum Bisnis). Bandung. PT. Citra Adiya Bakti (2007)

[16] Cotula, L, Vermeulen, S, Mathieu, P and Toulmin, C.: Agricultural investment and international land deals: evidence from a multi-country study in Africa. Food Secur. vol. 3 (S1) pp. 99-113 (2011)

[17] Jacoby, H, G and Mansuri, G.: Land tenancy and non-contractible investment in rural Pakistan. Rev. Econ. Stud. vol. 75 (3). pp. 763-788 (2008) 